\title{
As MÚlTiPlaS FIGURAS DE POVO EM DISCURSOS DE MAQUIAVEL $^{1}$
}

José Luiz Ames ${ }^{2}$

\begin{abstract}
Resumo: Na leitura das três obras políticas maiores de Maquiavel, é recorrente o uso do termo popolo, ou algum correlato. Assim, se parece evidente o interesse de Maquiavel pela figura "povo", o que ele entende por ela? Será possível fixar uma concepçáo suficientemente homogênea e definitiva de povo, no pensamento maquiaveliano, particularmente em Discursos? O propósito deste estudo é mostrar que, embora se faça presente uma ideia de popolo como ator político, na obra de Maquiavel, sua concepção não se deixa fixar de modo definitivo, menos ainda que ela possa ser homogênea e estática. Ao invés disso, pode-se sustentar que a concepção de povo, em Discursos, é polimórfica e varia segundo as conjunturas históricas concretas nas quais ele emerge na cena pública, de forma que se trata de uma ideia em permanente e contínua transformação.
\end{abstract}

Palavras-chave: Maquiavel. Povo. Discursos sobre Tito Lívio. Liberdade. Participação política.

\section{INTRODUÇÁO}

$\mathrm{Na}$ leitura das três obras políticas maiores de Maquiavel - $O$ príncipe, Discursos e História de Florença -, é difícil ler uma página sem deparar-se com o termo popolo, ou algum outro correlato (popolani, populare(i), plebe, moltitudine, minori, vulgo, universale etc.). Assim, se parece evidente o interesse de Maquiavel pela figura "povo", o que entende por ela? Será possível fixar uma concepção suficientemente homogênea e definitiva de povo, no pensamento maquiaveliano, particularmente em Discursos?

\footnotetext{
${ }^{1} \mathrm{O}$ presente trabalho integra projeto de pesquisa financiado pelo $\mathrm{CNPq}$, com a concessão de bolsa de pesquisa em produtividade e, de setembro de 2017 a agosto de 2018, com bolsa de pós-doutorado na Universidade de Urbino, Itália, sob a supervisão de Stefano Visentin.

2 Professor Associado da Universidade Estadual do Oeste do Paraná (UNIOESTE), Toledo, PR Brasil. (D) https://orcid.org/0000-0002-6763-5321 E-mail: jluizames@gmail.com
}

http://doi.org/10.1590/0101-3173.2020.v43n2.08.p133

\section{(i)}


Se dermos crédito às interpretaçôes de alguns comentadores contemporâneos de Maquiavel, parece perfeitamente possível oferecer uma resposta afirmativa a essa questão. Para Quentin Skinner, por exemplo, povo é uma matéria destituída naturalmente de virtù, cabendo ao príncipe - sob um principado - e à lei - sob uma república - a tarefa de inculcá-la nele, "de modo a forçá-lo [o povo] a colocar o bem de sua comunidade acima de todos os interesses egoístas" (SKINNER, 1988, p. 100). A tendência de encontrar em Maquiavel uma concepçáo bem definida de povo pode ser encontrada até em comentadores, como Maurício Suchowlanski, os quais criticam visóes como a de Skinner, ainda que, no final, acabe recaindo numa concepção semelhante. No entendimento do comentador, o que marca a concepção de povo, nos Discursos, é a ambiguidade em relação à sua capacidade para a ação política: Maquiavel não deixaria claro se se trata de súditos ou de cidadãos. No final das contas, porém, "povo" se revelaria um ente passivo, sempre suscetível de cooptação pelas elites: "Assim" - escreve Suchowlanski - "se os Discursos não atribuem ao povo um papel proeminente e importante na vida política da república romana, a capacidade da plebe de exercer a ação diretamente qualifica-se aparentemente por referências de Maquiavel a cooptação bem sucedida desta pelas elites".

Finalmente, se, na maior parte das vezes, Maquiavel é identificado pela tradição interpretativa por sua passividade, há também quem o situe no polo oposto, como John McCormick (2011, p. 16):

Maquiavel elogia claramente arranjos institucionais em que o povo participa diretamente do governo, isto é, onde o povo formalmente delibera em assembleia e decide as próprias leis; mas também que endossa formas indiretas de governo, tais como procedimentos eleitorais por meio dos quais o povo escolhe os magistrados que o governa por períodos intermitentes de tempo.

Esta breve introdução permite situar nosso propósito neste trabalho. $\mathrm{Na}$ verdade, ele é duplo: de um lado, evidenciar a inconsistência de algumas das mais conhecidas interpretaçóes acerca da concepção de povo, nos Discursos de Maquiavel; de outro - e em oposição a essa tradição interpretativa - mostrar que, embora se faça presente uma ideia de povo como ator político, na obra de Maquiavel, sua concepçáo não se deixa fixar de modo definitivo, menos ainda que ela possa ser homogênea e estática; ao contrário, pode-se sustentar que,

${ }^{3}$ Between Citizen \& Subject: Placing the People in Machiavelli’s Political Imagination (texto digital). 
ao invés disso, a ideia de povo em Discursos é polimórfica e varia segundo as conjunturas históricas concretas nas quais ele emerge na cena pública, de sorte que se trata de uma ideia em permanente e contínua transformação.

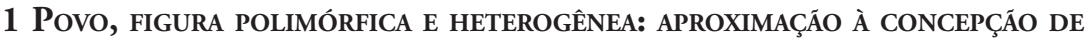 POVO EM DISCURSOS}

A discussáo dessas distintas perspectivas a propósito do lugar do povo em Discursos, segundo a tradição interpretativa, nos permite apontar para alguns equívocos comuns na compreensão dessa ideia de Maquiavel. Nosso esforço, a seguir, será o de explicitar qual é e como apreender a ideia de povo, nos Discursos de Maquiavel.

Os estudiosos da obra de Maquiavel, em geral, reconhecem a dificuldade de alcançar uma definição precisa sobre a ideia de povo. Não é nosso propósito aqui inventariar os estudos dedicados ao tema. Assumimos, como ponto de partida, a ideia já avançada por diversos intérpretes contemporâneos de Maquiavel, segundo a qual "povo" precisa ser compreendido sob o registro político ${ }^{4}$.

Que implica partir da ideia de que povo, em Maquiavel, pode ser captado apenas sob o registro político? De acordo com Sérgio Cardoso (2015, p. 226), implica admitir que "povo" está destituído de qualquer substancialidade, pois, tomado como humor/desejo, é captado unicamente como atividade (isto é, como pulsão ou desejo): "Estas noçóes [grandes/ povo] [...] referem-se a realidades cuja existência se determina apenas em sua atividade, no antagonismo fundamental pelo qual se encena a ordem política”, esclarece o comentador. Entendimento semelhante é também o de Stefano Visentin (2015, p. 369):

\footnotetext{
4 Sérgio Cardoso (2015, p. 235), em sugestivo estudo sobre a concepçấo de conflito em Maquiavel, enfatiza que só é possível captar adequadamente a ideia de povo, no autor, sob o registro político: “É preciso atenção para evitar atribuir às noçôes de 'grandes' e 'povo' realidades substantivas (tomálos como 'coisas'), a serem apreendidas em si mesmas, seja enquanto entidades imediatamente empiricamente - apreensíveis, seja enquanto definidas por determinaçôes psicológicas ou sociológicas”. Da mesma convicção partilham, entre outros, Lefort (1971, p. 381-382): "[...] grandes e povo não são tais por sua fortuna, costumes, função, interesses específicos e divergentes; o que os faz tais é o desejo de oprimir de uns e o desejo de não ser oprimido de outros - dois desejos insaciáveis"; Pedullà (2011, p. 339): "Não existe um só povo em abstrato. Existe o povo que se defende para não sucumbir à dominaçấo dos nobres e existe o povo que ataca"; e G. Inglese (2006, p. 90): "é impossível dar uma face unívoca, a partir de uma perspectiva sócio-histórica, ao que Maquiavel chama 'povo"'; S. Visentin (2015, p. 369): "o povo de Maquiavel [...] não tem qualquer realidade substancial, uma vez que só existe na medida em que aparece na cena política".
} 
[...] o povo de Maquiavel - assim como o príncipe novo - não tem qualquer realidade substancial, uma vez que só existe na medida em que aparece na cena política: é exatamente o que parece ser, e sua modalidade de açáo é completamente determinada pela imagem específica que assume enquanto fica à vista.

Tanto Visentin quanto Cardoso nos chamam a atenção ao que significa determinar a existência de povo como atividade: na medida em que o "ser" do povo se mostra na ação, não é possível determinar algo como uma "ideia" ou "conceito" de povo, muito menos um "conteúdo" empírico de tipo sociológico ou econômico. Conforme a famosa expressão de $O$ príncipe (cap. XV), Maquiavel procura estabelecer a verità effettuale della cosa. Isso náo é mais do que afirmar que a verdade da ação pode ser captada unicamente por meio de seus efeitos e não pelas motivaçôes ou por algo intrínseco à coisa mesma: quer dizer, a verdade se situa nas consequências, nas repercussóes - sejam elas afortunadas ou infelizes - sobre o sistema complexo das condiçốes a partir das quais a ação se desenrola. Uma vez que aquilo que o povo é (e o mesmo poderíamos dizer dos grandes) se mostra na ação, tornar-se "visível" implica ocupar um espaço na cena política. Fabio Frosini (2010, p. 104, grifos do autor) analisa essa questão, em uma passagem elucidadora:

Existe uma constante dialética que alimenta o espaço político enquanto espaço especificamente público, isto é, estruturalmente discutível (e, portanto, ainda não decidido), homogêneo (e, portanto, igualitário) e indisponível (e, portanto, comum). Esta dialética impede ao espaço (re) converter-se em uma estratificação natural, com a atribuição privada do todo a uma só parte (ou a um conjunto de partes). Contudo, esta [dialética] é estruturalmente assimétrica: a colocação espacial do povo determina sua luta como a única que pode ter real interesse na liberdade enquanto existência de um espaço público. Nem os grandes, nem o príncipe podem ter interesse nisto.

Assim, considerando que o "ser" do povo se torna visível unicamente na açáo e esta acontece sempre em um espaço político entendido como espaço público, estamos defrontados com o desafio de caracterizar os possíveis "modos" desse aparecimento, particularmente em Discursos. Nossa tentativa parte da hipótese desenvolvida pelos estudos de Visentin, em trabalhos anteriores (VISENTIN, 2013, 2015), nos quais descreve quatro distintas "faces" ou "figuras" de povo: povo como plebe, povo como multidão, povo como príncipe e povo como facção. A última dessas figuras, segundo o 
comentador, aparece particularmente em História de Florença e não será tratada aqui. Neste trabalho, partiremos da hipótese de trabalho, sugerida por Visentin, de que povo é uma figura polimórfica que aparece na cena pública sob uma "face" determinada, de acordo com a conjuntura histórica concreta. Nossa contribuição a essa hipótese consiste em investigá-la também a partir de outras passagens da obra de Maquiavel e pelo aprofundamento daquelas já tratadas por Visentin.

\section{Povo COMO NÁO-GOVERNo}

Um primeiro modo de o povo tornar-se visível na cena pública é, para Visentin, "povo como plebe", figura esta que se mostraria, sobretudo, na "doutrina dos humores". Preferimos caracterizar esse modo de aparecer de "povo como não-governo". Pensamos que descrever o aparecimento de povo como plebe poderia levar ao entendimento de que existiria para Maquiavel, em Discursos, uma distinção conceitual entre "plebe" e "povo", à semelhança do que existia na Roma antiga, onde plebe correspondia à parte excluída da sociedade política. Conforme Zancarini (2001) chama a atenção, "Maquiavel emprega indiferentemente um e outro termo [povo e plebe] sem introduzir uma única nuance entre eles". O exemplo paradigmático desse tratamento referido por Zancarini é a passagem de Discursos I, 45: primeiro, Maquiavel fala em Io dico che coloro che dannono i tumulti intra $i$ Nobili e la Plebe [... J" (DISCURSOS, I, $4)^{6}$; algumas linhas mais adiante, Maquiavel (DISCURSOS, I, 4) acrescenta: "i modi era straordinarii, e quase efferati, vedere il popolo insieme gridare contro al Senato, il Senato contro al Popolo, correre tumultuariamente per le strade, serrare le botteghe, partirsi tutta la plebe di Roma". A palavra "plebe", nesse contexto, possui seu sentido latino e não se distingue de "povo", esclarece Zancarini. Dessa forma, a luta dos humores caracterizada por Maquiavel, nos Discursos, é uma oposição permanente entre povo ou plebe, de um lado, e grandes ou nobres ou senado, de outro.

\footnotetext{
${ }^{5}$ Citaremos a obra "Discursos sobre a primeira década de Tito Livio", referindo a primeira palavra do título (Discursos), seguido da parte em algarismo romano e o capítulo em algarismo arábico, seguindo costume já firmado na área.

6 "Digo que aqueles que condenam os tumultos entre os Nobres e a Plebe".

7 "Os modos eram extraordinários, e quase cruéis, ver o povo em conjunto gritar contra o Senado, o Senado contra o povo, correr tumultuosamente pelas ruas, a fechar o comércio, a plebe toda indo embora de Roma".
} 
Considerando o esclarecimento de Zancarini acerca do significado dos termos povo e plebe, nos Discursos, pensamos que esse primeiro modo de aparecimento do povo à cena pública ficaria caracterizado de maneira mais precisa, designando-o "povo/plebe como não-governo". Pretendemos, com essa expressão, assinalar a posição de povo/plebe como negatividade, no sentido de resistência ativa à opressão exercida pelos grandes/nobres. Nessa linha, afirma-se uma relação assimétrica entre aqueles que comandam/governam (grandes) e os que resistem ao comando/governo (povo/plebe). Muito embora a resistência de povo/plebe dê origem a leis e instituiçôes favoráveis à vida política livre, revelando-se uma verdadeira "potência constituinte", não se trata do confronto entre dois desejos homogêneos de governar, como, levando-se às suas últimas consequências, a ideia de "positivação do desejo popular", por exemplo, poderia dar a entender. Essa compreensão faz eco ao que escreve Lefort (1971, p. 386, grifo nosso), referindo-se à oposição povo-grandes, em Maquiavel:

Se há uma honestidade e uma fidelidade populares, [...] estas somente se dão quando o desejo de não ser oprimido, em si mesmo impotente para apreender seu objeto, para realizar-se na forma de um poder que é ao mesmo tempo não-poder, encontra sua medida, ao chocar-se contra o terceiro que o inscreve na realidade da ordem política.

A mesma perspectiva, parece-nos, defende também Vatter (2014, p. 311), quando escreve:

A título de contraste, defendo que a chave para uma vida política livre está em construir um Estado que está aberto à contestação de forças sociais animadas pelo princípio do náo-poder [no-rule] e que por si só pode dar origem a leis e ordens capazes de manter sob controle tanto a dominaçáo do Estado quanto daqueles com poder na sociedade.

Raimondi (2013, p. 147, nota 17) alerta que, com essa ideia, "Vatter arrisca-se a uma posição anarquizante insistindo sobre o no-rule do povo, porque acaba por afirmar a necessidade do domínio para que se manifeste a liberdade (não-domínio) como resultado para obter uma liberdade jamais capaz de consolidar-se e durar". Na posição de Vatter se ocultaria a ideia de que o Estado é necessário, para que se manifeste a liberdade do povo. A crítica de Raimondi a Vatter se deve ao fato de Raimondi interpretar a ideia de norule como coincidindo com a ideia lefortiana de "negatividade pura". 
Não estamos seguros de que Lefort (1972, p. 477) - e, por conseguinte, também Vatter - entenda por "negatividade pura" do desejo popular o mesmo que recusa de ação, passividade, como Raimondi deixa entender. Em nosso entendimento, a ideia de no-rule de Vatter, assim como a de negatividade pura de Lefort, são compatíveis com o entendimento expresso por Raimondi (2013, p. 147), de que a liberdade maquiaveliana "[...] é um ordenamento que se rege pelo humor de não-domínio enquanto produtor de instituiçôes que impedem o domínio ou o destroem quando se apresenta sob a forma de corrupção". Quando tomamos povo como não-governo, nós nos referimos a uma posição de "resistência ativa" do povo ao desejo de opressão dos grandes, de cujo confronto resultam as leis e instituiçôes que regem a república.

É o sentido em que também Borrelli parece entender a questão, quando escreve que povo "constitui aquela parte consciente de ter de produzir ativamente dispositivos jurídico-institucionais idôneos à defesa contra as pretensôes excessivas dos grandes" (BORRELLI, 2017, p. 61). A ideia de nãogoverno é negativa, no sentido de compreender que o povo é sempre exterior ao exercício do governo da cidade. O humor popular de "não ser dominado nem oprimido" pressupóe a existência de seu par oposto, de "dominar e oprimir". Somente porque existe essa tensão, tem-se a possibilidade da vida política. Nesse sentido, talvez seja realmente inevitável que exista "o domínio para que se manifeste a liberdade (não-domínio) como resultado para obter uma liberdade jamais capaz de consolidar-se e durar", como Raimondi critica em Vatter.

O aparecimento de povo/plebe como "não-governo", ao obrigar seu par oposto - grandes/nobres - "a conceder ao povo a sua parte" (DISCURSOS, I, 2), o institui como ator coletivo político. Afirmar que povo é "ator" coletivo político o afasta, de um lado, da ideia de "sujeito histórico substancial" (sociológica ou economicamente determinado). Por outro lado, afirmar que se trata de um "aparecimento" do povo na cena pública - ao dizer que se trata de um "ator" - indica que o povo apenas se constituiu como personagem político, a partir do momento em que toma posição em relação ao poder exercido pelos grandes (nobres/senado). O povo aparece em conjunturas políticas críticas, quando toma consciência de suas reivindicaçôes negadas, transformando-se em um ator, construtor da história, quando força a alteração do jogo de forças, ao buscar dar existência às suas aspiraçôes.

Podemos formular essa ideia ainda do seguinte modo: é a partir da negatividade das necessidades que a luta pelo reconhecimento político levada 
a efeito pelo povo se transforma em mobilizaçóes reivindicativas, das quais nascem as leggi et ordini que fundam a liberdade da ordem política. Antes - ou fora - disso, o povo não se constitui em ator político coletivo. Antes - ou fora - de sua luta, o povo é como se estivesse invisivel, pois não aparece na cena política como sujeito. É multiplicidade sem objeto.

Compreender povo como ator resulta no entendimento de que ele só é alguém, isto é, tem identidade, na medida em que age na cena pública. $\mathrm{Na}$ medida em que o povo/plebe se posiciona em relação aos grandes, na afirmação de suas reivindicaçôes negadas, ele adquire realidade, ser, que, no entanto, se esgota nesse aparecer. Significa dizer: esse aparecimento não dá origem a algo, uma matéria ou conteúdo, como uma classe econômica ou segmento social pela qual adquiriria permanência e continuidade no tempo.

Não existe, para Maquiavel, uma "identidade" de povo que o constitua como sujeito estável e permanente na cena política. O povo, uma vez alcançada a reivindicação até então negada, "desaparece” (nesta identidade, ou feição), para reaparecer em nova conjuntura crítica (com a mesma ou outra feição). Com isso, "povo" é sempre exterior. Não se identifica jamais com a potestas, com a estrutura de poder instituída. Povo é, nesse sentido, "não-governo", um ator coletivo político que age politicamente fora da esfera das instituiçóes políticas. Sua ação se desenvolve livremente, fora do âmbito formal do governo da cidade. Exatamente porque age fora das estruturas formais da ordem política instituída, sua ação se desenvolve numa função "constituinte" da política.

O papel constituinte da ordem político-jurídica romana exercido pelo povo é destacado por Maquiavel, em diferentes modos e momentos da vida romana. A primeira é na origem da forma republicana de governo, em Roma. Repúblicas, pensa Maquiavel (DISCURSOS, I, 2), podem vir à luz somente de dois modos - e, para ilustrá-los, recorre à comparação entre Roma e Esparta: "[...] algumas receberam leis, em seu princípio ou depois de não muito tempo, de um só homem e de uma só vez - como as leis que foram ditadas por Licurgo aos espartanos - e outras as receberam ao acaso e em várias vezes, segundo os acontecimentos, como ocorreu com Roma”. Esparta "pode considerar-se uma república feliz", pois ordenou "de tal modo as leis em Esparta que, dando aos reis, aos optimates e ao povo suas devidas partes, criou um estado que durou mais de oitocentos anos, com supremo louvor para si e sossego para aquela cidade" (DISCURSOS, I, 2). Roma, pelo contrário, "embora não tivesse um Licurgo que a ordenasse de tal modo, no princípio, que pudesse viver por longo tempo livre, foram tantos os acontecimentos 
(accidenti) que nela surgiram, pela desunião que havia entre a plebe e o senado, que aquilo que não havia feito um ordenador, o fez o acaso" (DISCURSOS, I, 2). O "acaso" ao qual Maquiavel remete a origem da constituição mista da república romana corresponde "à desunião entre a plebe e o senado".

O segundo momento em que se mostra a função constituinte exercida pelo povo é na origem do governo misto, em Roma. O texto do segundo capítulo dos Discursos atribui a paternidade da constituição mista romana exclusivamente aos conflitos entre povo e grandes. Roma, após a expulsão dos reis, possuía duas das três instituiçóes fundamentais que definem o governo misto, ou seja, "o principado e os optimates", sendo o primeiro exercido pelos cônsules (órgão de representação régia) e o segundo pelo senado (órgão de representação dos patrícios). Faltava, portanto, "somente dar lugar ao governo popular", a fim de que a constituição alcançasse a "perfeição". Maquiavel (DISCURSOS, I, 2 - grifos nossos) descreve da seguinte maneira o processo de inserção da parte popular no governo da república:

[...] tornando-se a nobreza romana insolente [...], o povo sublevou-se contra ela; e assim para náo perder tudo, ela foi obrigada a conceder ao povo a sua parte [...]. E assim se criaram os tribunos da plebe, tornando-se mais estável o estado daquela república, visto que as três formas de governo tinham sua parte.

A inclusão do povo no governo republicano não resultou de uma concepção abstrata de constituição mista, mas de um ato de força, uma "sublevação", ou um "levante popular" (si levò il popolo, escreve Maquiavel) contra a nobreza. Tanto na origem da república quanto em sua forma mista se encontra o povo como potência instituinte, em sua luta contra as pretensóes de monopólio do exercício do poder pelos grandes.

Em um terceiro momento, Maquiavel mostra que os conflitos são a primeira - e até mesmo a única - fonte da qual se originaram todas as estruturas institucionais que cooperaram positivamente para a grandeza e a liberdade romanas, constituindo-se na verdadeira causa de todo bem político. Essa concepção se apoia sobre a ideia segundo a qual os conflitos são inerentes à vida política de todas as cidades, as quais são naturalmente divididas em grandes e povo:

Digo que aqueles que condenam os tumultos entre os nobres e a plebe me parece que censuram aquelas coisas que foram a causa primeira que manteve livre Roma, e que consideram mais os rumores e a grita que de 
tais tumultos nasciam do que os bons efeitos que geravam; e que não consideram que em toda república existem dois humores diferentes, o do povo e o dos grandes e que todas as leis que se fazem a favor da liberdade nascem da desunião entre eles (DISCURSOS, I, 4, grifos nossos).

Ao afirmar que o conflito é a fonte de "todas as leis que se fazem em favor da liberdade", Maquiavel dá a entender que não seria possível manter a liberdade republicana, se não houvesse o confronto entre grandes e povo. É como se concebesse que, se não existisse quem não quer ser dominado $\mathrm{e}$, de outro, quem quer dominar, também não existiria o espaço político do vivere libero, mas tão somente luta por bens e interesses privados. Sem a dinâmica do conflito entre os humores de grandes e povo não existiria vida política, pura e simplesmente.

Finalmente, em um quarto momento, Maquiavel (DISCURSOS, I, 5) assinala que, entre as principais preocupaçôes dos ordenadores de repúblicas, “[...] está a constituição de uma guarda da liberdade [pois] dependendo do modo como esta for instituída, dura mais ou menos tempo aquela vida livre". Uma vez que "em toda república existem homens grandes e populares" (DISCURSOS, I, 5), é preciso decidir a quem deve ser confiada a guarda. Trata-se de uma decisão política, não jurídica. Como decidir? Maquiavel voltase para as experiências históricas de regimes que fizeram escolhas diferentes: de um lado, Roma, que a colocou nas mãos do povo; de outro, Esparta e Veneza, que a confiaram aos grandes. Após examinar detidamente as duas alternativas, e considerando que se deve "colocar a guarda de alguma coisa naqueles que têm menos desejo de usurpá-la" (DISCURSOS, I, 5), Maquiavel (DISCURSOS, I, 5) conclui que o povo é melhor guardião da liberdade que os grandes: considerando i fini de grandes e povo, veremos que "[...] naqueles há grande desejo de dominar e nestes somente o desejo de não ser dominado e, por conseguinte, maior vontade de viver livre, visto que podem ter menos esperança de usurpar a liberdade do que os grandes".

Em todos esses momentos de invenção e constituição de ordenamentos político-jurídicos, a ação do povo está vinculada à luta por liberdade. Isto é devido, de um lado, à subalternidade da posição ocupada no confronto, mas igualmente ao desejo de livrar-se da opressão exercida pelos grandes desde o lugar "alto". São, pois, dois os condicionantes. Por um lado, o povo não teria como vincular sua luta à liberdade, se não estivesse na posição subalterna, dominada: não é acidental a vinculação da liberdade com resistência à opressão. 
Somente aquele que sofre a opressão pode querer a liberdade, jamais quem a exerce. Por isso, é impossível aos grandes vincular sua ação à instauração da liberdade, dada sua colocação espacial de comando e dominação. Por outro lado, a vinculação do povo à liberdade seria vazia se nele, povo, não existisse um desejo de livrar-se da opressão.

Maquiavel chama a atenção a essa questão nos capítulos 16 a 18 do Livro I dos Discursos. No capítulo 16, mostra que um povo "acostumado a viver sob a autoridade de um príncipe" dificilmente conserva a liberdade, se eventualmente a conquista. O mais certo de acontecer, afirma Maquiavel, "é logo se submeter de novo ao jugo" (DISCURSOS, I, 16). Maquiavel ressalta que a liberdade só tem chance de florescer ali onde existe resistência à opressão exercida pelos grandes, mas igualmente na medida em que houver recusa de ser servo, de submeter-se voluntariamente ao jugo. A liberdade não é um dado, é resultado da luta, da resistência à opressão, mas também resistência ao desejo de submeter-se ao jugo, de desistir de lutar.

Os grandes, precisamente porque seu humor se determina por um desejo de dominar, exercem uma ação no espaço público inconciliável em linha de princípio com a liberdade. O desejo de "não ser dominado" da parte do povo é resistência ativa e propositiva ao "desejo de dominar" dos grandes. A "negatividade" do desejo popular está longe de ser entendida por Maquiavel como passividade. O povo é apresentado como ator coletivo político ativo, embora não tenha pretensão ao exercício direto e pessoal do governo. Com efeito, Maquiavel demonstra que o povo, ainda que pudesse escolher dentre seus pares, em geral elege representantes para os Tribunos e outras magistraturas entre os grandes (DISCURSOS, I, 47). Assim, sua luta para sair da subalternidade de sua relação com os grandes dá-se muito mais pela criação de mecanismos institucionais de controle da ação destes do que pelo exercício direto das funçôes públicas.

Falar de povo como "ator coletivo político" significa, pois, que povo passa da invisibilidade à visibilidade, na cena pública, ao constituir uma identidade definida por sua resistência à opressão. Em Discursos, Maquiavel evidencia com clareza que o povo demarca sua posição como contrária às pretensóes dos grandes; isto é, Maquiavel descreve o povo como um ator que se confronta com outro, ou seja, os grandes. O povo se configura como corpo que tem aspiraçóes inconciliáveis com as de seu oponente político e, ao dar expressão a essas aspiraçóes, força seu oponente a remodelar sua ação. A ação 
popular deixa explícito o papel constituinte exercido pelo povo, na formação da república romana, na visão de Maquiavel.

Em suma, a forma predominante de aparecimento do povo/plebe nos Discursos é de não-governo. Ele se torna ator político coletivo, ou seja, dá-se uma identidade, quando emerge na cena pública como força de resistência à opressão dos grandes. A dinâmica de scontrolencontro entre os dois humores origina os ordenamentos político-jurídicos que asseguram a liberdade da cidade. Essa figura não é constante, nem tem sempre a mesma forma de aparecimento. Em geral, escreve Maquiavel (DISCURSOS, I, 4), vê-se “[...] o povo em conjunto a gritar contra o senado o senado contra o povo, a correr em tumulto pelas ruas, a fechar o comércio, a sair toda plebe de Roma [...].” Em seguida, acrescenta um exemplo elucidativo: "Quando o povo queria obter uma lei, ou fazia alguma das coisas acima citadas, se negava a arrolar seu nome para ir à guerra, de tal modo que, para aplacá-lo, era preciso satisfazê-lo em alguma coisa" (DISCURSOS, I, 4). A ação popular obriga o humor oposto a remodelar sua ação. As leggi et ordini nascem dessa relação de scontrolencontro.

Nota-se, por conseguinte, que o povo age politicamente fora da esfera das instituiçôes formalmente instituídas, fora da formalização legal. É por essa ação "desordenada" (no sentido de que acontece fora da "ordem" legal) que o povo expressa suas reivindicaçóes negadas e alcança seus objetivos. As "leis em favor da liberdade pública" nascem, fundamentalmente, não dos debates nas assembleias, porém, especialmente, das ruas, da resistência do povo em relação às pretensóes dos grandes como, por exemplo, quando se nega estrategicamente a ir à guerra, a fim de alcançar seus objetivos.

\section{Povo COMO MULTIPLICIDADE CONSTITUINTE}

Considerando a inexistência de algo empírico, ou "natural", capaz de "manter unidos" os singulares que agem no espaço social, o que torna possível a essa dispersão individual, essa multidão, ficar "atada"? Na figura anterior, apontamos que a dispersão individual se funde numa unidade, na medida em que emerge na cena pública como ator coletivo político, quando aqueles que "náo querem ser comandados nem oprimidos" resistem ao desejo daqueles que "querem comandar e oprimir". Vimos que essa dinâmica de scontrol encontro na cena pública entre os humores que constituem o todo social faz com que os que são movidos pelo desejo de "não serem, comandados nem oprimidos" emerjam com uma identidade determinada, isto é, como "povo/ 
plebe", todavia, que se "invisibiliza", na medida em que alcança seus objetivos para reaparecer posteriormente sob a mesma ou outra figura.

Agora nos defrontamos com outra "face" pela qual o povo emerge no espaço público: multidão. No primeiro livro dos Discursos, Maquiavel se utiliza do termo "multidáo", para exprimir o caráter heterogêneo do povo e a sua irredutibilidade a qualquer princípio unitário, seja este antropológico, seja moral-religioso ou ontológico. Para os contratualistas, sobretudo Hobbes, a multidão é pura dispersão individual que passa a ter existência política unicamente na medida em que é reduzida à unidade do representante: a multidão é una somente no e pelo soberano como seu representante. Uma vez extinto este, tudo volta à dispersão original. Maquiavel não opera nesse plano conceitual. Não existe resquício da ideia de uma representação da multiplicidade em uma unidade artificial (de um "soberano" ou de um "representante"). No entanto, tem razão Hobbes, quando assevera que uma vida política é possível apenas se ela encontra unidade. Como Maquiavel não conhece o conceito de representação (com o qual Hobbes realiza a operação de unificação do múltiplo no uno), ele se defronta com o problema de pensar de que maneira é possível evitar o scioglimento, a dispersão da multidão em uma multiplicidade de indivíduos atomizados; ou seja, depara-se com a necessidade de determinar o que faz com que a multidáo permaneça tutti insieme e não se dissolva, quando não se pode contar com a figura unificadora de um "representante".

A passagem na qual Maquiavel descreve, de modo mais claro, a relação entre o singular e o múltiplo, ou entre príncipe e multidão, encontra-se em Discursos I, 58. Nesse capítulo, Maquiavel (DISCURSOS, I, 58) começa recordando o juízo negativo da multidão presente na tradição e resumida na máxima de Tito Lívio: "Essa é a natureza da multidão: ou serve com humildade ou domina com soberba”. Logo após recordar esse lugar comum da crítica à multidão, Maquiavel justifica sua posição contrária.

É importante frisar aqui que Maquiavel não está movido puramente pelo propósito de inverter, ou de negar, a mentalidade dominante, qual seja, de uma virtude dos optimates, ou de um indivíduo singular, como contraposta à irracionalidade da multidão. Antes, o que Maquiavel pretende com sua análise acerca do "negativo" da multidão é aprofundar os paradoxos do comportamento da multidão, para melhor estabelecer a constituição de um novo ponto de unidade, conforme esclarece Del Lucchese (2003, p. 143): "A ilustração do negativo da multidão é, pois, necessária como primeiro 
elemento a partir do qual se poderá fazer aparecer a virtude do múltiplo, em particular sua dimensão política”. Vejamos como essa dinâmica se desenvolve, no capítulo 58.

A primeira coisa a compreender na relação entre uno (de príncipe ou optimates) e multidão, no entendimento de Maquiavel, é "que do defeito que os escritores acusam a multidâo podem ser acusados todos os homens, particularmente e, sobretudo, os príncipes, porque qualquer um que não seja regulado pelas leis cometeria os mesmos erros que comete a multidão desatada (sciolta)" (DISCURSOS, I, 58, grifos nossos). Seria um equívoco, continua Maquiavel, um pouco adiante, "culpar a natureza da multidão mais que a dos príncipes", porque ambos erram quando podem agir "sem temer as leis" (DISCURSOS, I, 58, grifos nossos). Não se pode invocar a natureza como princípio explicativo do comportamento político dos homens. Com efeito, conclui Maquiavel (DISCURSOS, I, 58, grifos nossos): “[...] a variação do proceder [de príncipes e multidão] nasce não de diferenças de natureza porque esta é em todos de um só modo - [...], mas do maior ou menor respeito às leis sob as quais um e outro vive". O scioglimento, isto é, a possibilidade de cada um poder agir seguindo tão somente seu arbítrio, é algo que afeta por igual a príncipes e multidão. Um príncipe que age sem "respeito às leis" não é menos perigoso para um vivere libero et civile do que o é uma multidão. A multidão, insiste Maquiavel, permanecerá tutti insieme e não se dispersará somente quando "amarrada" às leis ${ }^{8}$.

A questão toda se resume, portanto, em saber como evitar que a ação, tanto da multidão quanto do príncipe, não seja sciolta, não seja "desatada", sem freios. Maquiavel, vimos, descarta a opinião comum estabelecida para a qual o agir sciolto é um defeito do qual se pode acusar somente a multidão, mas não os optimates e os príncipes. Para Maquiavel, semelhante posição não se sustenta. Não existe qualquer diferença "natural" entre os homens que

\footnotetext{
${ }^{8}$ Os riscos que corre a vida política, quando exposta à moltitudine sciolta, é destacada por Maquiavel náo apenas nos Discursos, mas também em outros momentos, especialmente em História de Florença (III, 14), quando descreve os desdobramentos da revolta Ciompi. Maquiavel destaca ali que a multidão, empolgada após o discurso do ciompo anônimo, enquanto se preparava para "ocupar a república", reuniu-se na praça e "saiu a queimar as casas de muitos cidadãos, perseguindo aqueles que, por razốes públicas ou privadas, eram odiados" (História de Florença III,14, p. 188). Bastava, escreve Maquiavel, que "alguma voz se erguesse no meio da multidão gritando a casa il tale" para que a moltitudine sciolta corresse até lá para incendiá-la. O risco de uma moltitudine sciolta que age como um corpo único consiste no fato de sua ação ser levada a efeito sem qualquer plano racional. O que a move é a pura irracionalidade das paixôes sem freios. $\mathrm{O}$ resultado de semelhante movimento não é o melhoramento do vivere político, e sim, em última instância, a tirania.
} 
autorize a pensar que as virtudes possam distribuir-se naturalmente segundo o estrato social, pois todos estão afetados pelas mesmas paixóes ${ }^{9}$. A diferença de natureza, portanto, não pode ser responsabilizada pela scioltezza, mas ela também não possui nela mesma a capacidade de tornar os homens vincolatos. A solução que Maquiavel visualiza, para evitar a scioltezza, tanto de príncipes quanto da multidão, é um conjunto institucional adequado pelo qual ambos sejam "regulados" pela lei. "Amarrados" à lei, os príncipes governam de maneira virtuosa, e a mesma virtude pode ser encontrada na multidáo presa à lei. Uma multidão regulada pela lei, afirma Maquiavel (DISCURSOS, I, 58), "não domina com soberba nem serve com humildade", invertendo, dessa maneira, o juízo de Tito Lívio lembrado pelo florentino ${ }^{10}$.

Aqui podemos lembrar aquilo que explicitamos na análise da figura anterior, ou seja, de que as leis que "regulam" a multidão não são forças constritoras externas, "heterônomas", e sim resultado dos conflitos, isto é, do movimento de resistência à opressão exercida pelos grandes e príncipes. As leis que "regulam" a multidão são, portanto, princípios "autônomos" (no sentido de que se originam da resistência popular à dominação dos grandes) que manifestam o poder e a virtude da multidão.

Uma vez, pois, que a natureza é a mesma em todos os homens, fica destituído de valor o julgamento da tradição que atribui aos príncipes e optimates uma racionalidade superior. Por conseguinte, não há razão para se negar à multidão seu acesso à cena política em igualdade com os demais atores. Contra, portanto, a commune opinione (DISCURSOS, I, 58) firmemente estabelecida, Maquiavel confere uma dignidade e uma racionalidade políticas à multidão.

Maquiavel vai ainda mais longe: não apenas defende a igualdade de natureza de príncipes e multidão - de modo que não só da multidão como também dos príncipes se pode dizer "que são variáveis, mutáveis e ingratos" (DISCURSOS, I, 58) - como afirma a superioridade da virtù da multidão

\footnotetext{
9 Veja-se, a propósito, o que Maquiavel escreve no texto "Do modo de tratar os povos do Vale do Chiana rebelados" (p. 93): "o mundo sempre foi, de certa forma, habitado por homens que sempre tiveram as mesmas paixôes; e sempre houve quem serve e quem comanda, e quem serve de má vontade e quem serve de boa vontade, e quem se rebela e se rende". Igualmente pode ser conferida a passagem que consta em Discursos III, 43: "Isso ocorre porque, tendo sido feitas pelos homens, que têm e sempre tiveram as mesmas paixôes, tais coisas só poderão, necessariamente, produzir os mesmos efeitos".
}

10 "Essa é a natureza da multidão: ou serve com humildade ou domina com soberba" (Discursos I, 58). 
em relação à dos príncipes ${ }^{11}$, tanto na situação em que estão "amarrados" à lei quanto na situação inversa: "Se pensarmos num príncipe constrangido pelas leis e num povo acorrentado a elas, se verá mais virtù no povo que no príncipe; e se pensarmos em um e outro desatados (sciolti), se verá menos erros no povo que no príncipe" (DISCURSOS, I, 58). Mais adiante, no Livro III, Maquiavel (DISCURSOS, III, 29) é ainda mais enfático quanto à responsabilidade dos príncipes pelos erros do povo: os erros do povo "só podem nascer da negligência” de quem o governa. Por essa razão, pondera Maquiavel que, "se os príncipes são superiores aos povos na ordenação das leis, na formação da vida civil, no estabelecimento de novos estatutos e novos ordenamentos", é preciso reconhecer igualmente que "os povos são superiores na manutenção das coisas ordenadas" (DISCURSOS, I, 58). A "guarda da liberdade”, como escreve no capítulo cinco dos Discursos, é tarefa que se cumpre com êxito apenas quando confiada ao povo.

O reconhecimento de Maquiavel a respeito do comportamento muitas vezes ambíguo do povo não elimina nada de sua decisão de reconhecer o povo como ator político. Se o povo falha em seu julgamento das coisas gerais e se ele, por vezes, não tem por si mesmo a capacidade da ação coletiva, não é porque lhe faz falta a consciência histórica, mas porque as forças presentes no espaço político estão submetidas ao mesmo tempo à particularidade das situaçôes e à pluralidade dos pontos de vista.

O que Maquiavel pretende nos mostrar com essas consideraçóes, positivas e negativas, sobre o caráter da multidão? Parece-nos, antes de tudo, de que a racionalidade da multidáo nasce da e pela dinâmica da constituição da multidão como ator político. Não se poderia, por exemplo, sustentar, a partir do que referimos acima, que a única coisa que interessa a Maquiavel pudesse ser a pura e simples afirmação da superioridade da racionalidade que emerge da multidão em relação àquela que emerge do príncipe. Estamos de acordo com a avaliação de Visentin (2013, 2015), quando enfatiza que, ao invés disso, o que Maquiavel pretende ressaltar, com sua análise ponderada de príncipes e multidão, na constituição da vida civil, é que a racionalidade

\footnotetext{
${ }^{11}$ De acordo com Landi (2015, p. 123), o título de Discursos I, 58 "sustenta de maneira categórica a dupla superioridade, cognitiva e moral, do povo em relação aos príncipes". Segundo o comentador, é preciso colocar em exame a "opinião universal", isto é, a "opinião do povo" como mais sábia: "interpretado no contexto mais amplo, a ideia 'de uma superioridade cognitiva e moral' do julgamento do povo, ela se mostra questionável. Longe de ser uma simples epifania republicana, o adágio de Discursos I, 58 coloca na realidade à luz as ambivalências do julgamento de Maquiavel a respeito das faculdades cognitivas e morais da multidão" (LANDI, 2015, p. 137).
} 
que se atualiza por meio da multidáo é superior, náo apesar e sim enquanto (ou mesmo porque) emerge da multiplicidade. Em outras palavras, da mesma forma que, em um príncipe, sua racionalidade não se afirma em prejuízo de suas paixóes, mas contribui para organizar a dinâmica delas, assim também os conflitos de humores que se determinam na multidáo aumentam o poder dela.

Maquiavel expressa essa convicção, quando sublinha a superioridade das repúblicas (expressóes do múltiplo) sobre os principados (modalidades do uno). Encontramos essa ideia em diversos lugares de sua obra e, nos Discursos, pode ser lida quando escreve: "ainda que um só seja mais apto para ordenar, a coisa ordenada não durará muito se repousar sobre os ombros de um só, mas apenas quando for entregue aos cuidados de muitos, e a muitos couber mantê-la” (DISCURSOS, I, 9). A superioridade do múltiplo sobre o um está associada ao fato de o primeiro poder "adaptar-se mais facilmente às variaçóes dos tempos", como escreve Maquiavel, quando compara o modo de agir de Fábio e Aníbal, entre os romanos, e de Soderini e o papa Júlio II, na Itália de seu tempo: "uma república tem vida mais longa e mais demorada boa fortuna que um principado, porque pode acomodar-se melhor à diversidade dos tempos do que um príncipe em razão da diversidade dos cidadãos que nelas há" (DISCURSOS,, III, 9).

Essa maior capacidade de adaptaçáo do múltiplo, por sua vez, nasce do fato de a diversidade dos humores tornar possível imitar com maior êxito a diversidade da natureza. Assim, a maior racionalidade da multidão em relação ao príncipe é devida precisamente à multiplicidade, à sua maior capacidade de expressar a variedade das circunstâncias, dado que pode contar com uma diversidade de homens, cada qual com suas virtudes próprias, singulares, ao passo que um principado está limitado ao humor/virtude de um só.

Fica claro, dessa maneira, que a figura de povo como multidão "expressa a primazia da multiplicidade sobre a unidade" (VISENTIN, 2015, p. 376). Isso, porém, lembra Visentin (2015, p. 376), "não significa que a multidão está necessariamente em oposição à unidade, e sim que é sempre superior ao poder de um só". Além do que já mencionamos acima, Maquiavel reforça essa convicção, quando elogia a instituição da ditadura na república romana como "uma autoridade que se dá por vias ordinárias" (DISCURSOS, I, 34), isto é, submetida à lei, ao poder de muitos. Na situação inversa, ou seja, de uma autoridade absoluta, "em brevíssimo tempo corrompe a matéria, fazendo amigos e partidários” (DISCURSOS, I, 35). 


\section{O POVO NO PRÍNCIPE}

Trata-se, nesta terceira figura de povo, de pensar a relação entre unidade e multiplicidade em um sentido diverso da figura anterior. Se, na figura anterior, Maquiavel destaca a primazia constituinte da multidão sobre o príncipe, agora parece inverter a relação: em determinadas situaçóes, o povo parece ter necessidade de exprimir-se por meio de um chefe, não de alguém que substitua o lugar da multidão (como se fosse determinar um "representante"), e sim uma voz que fale por todos, pelo conjunto. A questão a examinar aqui é: essa "voz" que fala por todos provém do interior mesmo do corpo popular ou nasce de uma "cabeça" separada deste? A relação entre povo e príncipes, como sabemos, está no cerne da obra $O$ príncipe. Aqui iremos limitar nossa análise ao modo como ela é tratada por Maquiavel, em Discursos.

Desde os primeiros capítulos dos Discursos, encontramos passagens nas quais Maquiavel explicita sua compreensão da relação povo-príncipe (ou, em outras ocasióes, a relação mais geral entre povo e comandante, como a de um capitão na guerra, por exemplo). Como veremos, em momento algum de sua obra Maquiavel confere ao príncipe uma função representativa dos humores populares, como será o caso da modernidade posterior. Em Maquiavel, ao contrário, a relaçáo de povo e príncipe consiste muito mais em evidenciar de que maneira a autoridade do príncipe se relaciona com a forma pelo qual o povo imagina seu príncipe e, por conseguinte, como a ação deste é determinada por aquele. Com efeito, para Maquiavel, seria um equívoco pensar a ação política apenas da perspectiva daquele que governa. Se a verdade política pode ser captada unicamente por meio de seus efeitos, estes não se produzem puramente segundo um cálculo prévio daquele que governa, mas dependem do modo como as açóes são interpretadas pelos governados. A ação de quem governa é determinada pelo modo como o governado percebe a ação levada a efeito pelo governante.

Logo no começo dos Discursos (I, 2), Maquiavel descreve como, "no princípio do mundo", os habitantes "se reuniram e, para poderem melhor defender-se, começaram a respeitar aquele que, dentre eles, fosse mais forte e corajoso e, fazendo dele seu chefe, obedeciam-no". Mais tarde, continua Maquiavel, foi preciso escolher um príncipe; porém, tendo já surgido entre eles a ideia de justiça, acabou que "já não recorressem ao mais robusto, e sim ao que fosse mais prudente e justo" (DISCURSOS, I, 2). A relação príncipepovo reaparece sob um novo ângulo, mais adiante, quando Maquiavel ressalta o papel determinante do povo quanto à maneira de agir do príncipe: "Verdade 
é que julgo infelizes aqueles príncipes que, para assegurarem o estado deles, precisam valer-se de vias extraordinárias, visto terem por inimigos a multidáo; porque aquele que tem por inimigo os poucos facilmente e sem muito escândalo se assegura, mas quem tem o povo (l'universale) por inimigo nunca está seguro" (DISCURSOS, I, 16) ${ }^{12}$.

No capítulo seguinte de Discursos, Maquiavel reafirma sua posição enunciada no capítulo 9 do Livro I: a fundação e refundação da vida política é necessariamente liderada por um só homem. No contexto do capítulo 17, Maquiavel mostra que, sob uma república na qual a "matéria" - ou seja, o povo - está corrompida, esta só poderá ser recuperada "pela virtù de um homem que ainda esteja vivo, e não pela virtù do povo - dello universale" (DISCURSOS, I, 17). Essa posiçáo é reafirmada ao final do capítulo 18, quando Maquiavel reconhece a "quase impossibilidade" de manter ou criar uma república onde a corrupção atingiu o corpo político como um todo. De qualquer forma, afirma o florentino, "em se precisando criar ou manter uma [república], seria necessário reduzi-la mais ao estado régio do que ao estado popular a fim de que os homens cuja insolência não pode ser corrigida pelas leis fossem de algum modo freados por uma autoridade quase régia” (DISCURSOS, I, 18).

A mesma ideia é retomada no Livro III, quando Maquiavel escreve que a renovaçáo das repúblicas pode dar-se por leis capazes de reconduzir o corpo político à virtude, ou por ordenaçôes que ganham vida graças à virtù de um homem que as coloca em prática, isto é, graças "a algum homem bom que surja entre eles e que, com seus exemplos e suas obras virtuosas, produza o mesmo efeito de uma ordenação" (DISCURSOS, III, 1). Essas passagens revelam que as modalidades por meio das quais o príncipe institui sua autoridade passam pelo emprego de dois instrumentos: a concentração da força nas mãos de um chefe e a liderança virtuosa que consegue produzir de si mesmo uma imagem coerente com a expectativa popular.

Maquiavel é sem meias palavras, quando examina a capacidade do povo de tornar-se verdadeiramente um ator político. Mostra que o povo é uma força construtiva, quando está reunido, quando é posto em movimento por um ou vários indivíduos, seja numa república, seja num principado.

\footnotetext{
${ }^{12}$ Maquiavel retoma aqui o argumento já desenvolvido anteriormente, em $O$ príncipe (cap. 15 a 18): não é o príncipe que, desde sua subjetividade, define os meios, contudo, são as condiçôes objetivas para dar satisfação ao povo aquilo que é determinante do seu modo de açáo. Maquiavel tem claro de que a segurança de príncipe e povo é inseparável: o príncipe está seguro, quando pode contar com o favor popular; o povo, por sua vez, depende de capacidade organizativa de um príncipe, para assegurá-lo. Ao final das contas, enfatiza-se a mais uma vez que o povo age pelo príncipe.
} 
É o exemplo que refere no capítulo 44 do Livro I, o qual tem um título emblemático: "Uma multidão sem chefe é inútil". Nesse capítulo, Maquiavel conta a história da chamada plebis secessio - o acontecimento da retirada dos plebeus romanos para o Monte Sagrado, após a morte de Virginia. A plebe ficou muda quando embaixadores do Senado apareceram para negociar com ela, "não porque lhe faltasse matéria para responder, mas porque lhe faltava quem desse a resposta" (DISCURSOS, I, 44). Quando Valério e Horácio chegaram, a fim de ouvir as reivindicaçóes da plebe, "esta lhes pediu que fossem constituídos os tribunos da plebe, que todas as magistraturas precisariam recorrer ao povo, e que lhe entregassem os Dez porque queria queimá-los vivos" (DISCURSOS, I, 44). Valério e Horácio são a "cabeça" por meio da qual o "corpo" da plebe "expressa" suas reivindicaçóes. Para Visentin (2006, p. 249), com isso, evidencia-se que uma multidão sem chefe "se mostra incapaz de expressar plenamente a própria politicidade, de transformar em ato político os próprios desejos e as próprias paixôes”.

O capítulo 47 reforça o entendimento de que a plebe tem consciência da necessidade de uma "cabeça", por meio da qual suas aspiraçóes possam materializar-se. $\mathrm{O}$ argumento desenvolvido por Maquiavel está expresso no título: "Os homens, embora se enganem nas coisas gerais, não se enganam nas particulares". Maquiavel (DISCURSOS, I, 47) explica que a plebe considerava que o consulado deveria estar aberto à plebe, porque "[...] era maioria na cidade, porque se expunha a maiores perigos na guerra, porque com seus braços mantinha a liberdade de Roma e a tornava poderosa”. Quando, porém, a plebe teve de decidir quem dentre ela deveria ocupar o cargo, reconheceu "a fraqueza [de seus pares] e considerou que nenhum merecia aquilo que ela, em conjunto, acreditava merecer" (DISCURSOS, I, 47).

A passagem parece indicar que o povo entende que, como um todo, fez por merecer o reconhecimento como ator político da cidade, embora nenhum deles se mostre capaz de encarnar o status político adequado em sua própria pessoa. Para "confirmação" desse ponto, Maquiavel relata que um "certo" Pacuvius procurou reconciliar nobres e povo. Com a permissão dos próprios senadores, trancou estes no palácio e disse ao povo que "chegara a hora de domarem a soberba da nobreza e vingar-se das injúrias sofridas" (DISCURSOS, I, 47). Quando Pacuvius chamou o primeiro nome, o povo condenou sumariamente o senador escolhido à morte, por crueldade e arrogância, entretanto, quando foi instado a encontrar um substituto dentre os seus quadros, cada candidato proposto evocava o riso e a zombaria de seus 
próprios pares, reconhecendo que ninguém dentre eles era digno de exercer o cargo. Pacuvius concluiu desse ritual que os cidadãos comuns tinham conhecimento de que precisavam do senado, para não arrastar a cidade à anarquia. Novamente, Maquiavel procura assinalar que o povo reconhece a necessidade de uma "cabeça" para dar voz ao seu corpo.

No capítulo 57, Maquiavel escreve que "a plebe, unida, é forte; dispersa, é fraca”. A plebe romana, a qual constitui uma força temível frente ao senado, como Maquiavel ilustra nos capítulos iniciais dos Discursos, tornase uma moltitudine inútil, quando não tem quem a governe: "nada há de mais temível que uma moltitudine irrefreada e sem comando", escreve Maquiavel (DISCURSOS, I, 57). Para aceder à qualidade de sujeito político, na cidade, a multidão deve, pois, ser guiada e unificada em suas açôes: "precisa escolher em seu próprio seio alguém que a governe, que a mantenha unida e pense na sua defesa" (DISCURSOS I, 57). A “cabeça” que a "governa” e "pensa" emerge "de seu próprio seio". Para Borrelli, somente quando se torna capaz de ação conjunta se pode qualificar a multidão "como povo, aquela parte da cidade que tem inteligência e meios para sustentar o projeto político de subtrair-se ao domínio que os grandes buscam afirmar a qualquer custo" (BORRELLI, 2017, p. 60).

As passagens referidas demonstram que "a força do povo é paralela à identificação de suas fraquezas, seu peso na cidade, à sua relativização. E se os escritores políticos e se os príncipes ignoram, temem ou rebaixam esta força do povo, é porque a opinião geral lhe foi por longo tempo desfavorável e criou hábitos de pensamento que falseiam a realidade" (ION, 2015, p. 150). Em suma, a "voz" do príncipe não sai de uma "cabeça" separada do corpo popular, todavia, provém do interior do próprio povo. $\mathrm{O}$ povo dá voz a alguém que o faz falar e agir. A potência constituinte permanece no povo. Nas palavras de Visentin (2006, p. 250), "se não existem artifícios ou atos de vontade capazes de constituir o povo como princípio unitário, então também o capo que deve de algum modo manter unida a multidão pode unicamente emergir da própria multiplicidade, de uma convergência interna de forças e de paixões que arruína uma conflitualidade de outro lado insuperável”.

\section{CONSIDERAÇÓES FINAIS}

Esperamos haver mostrado que é equivocada a tentativa corrente, na tradição interpretativa, de fixar uma concepção homogênea e estática de povo, 
nos Discursos de Maquiavel. Ao invés disso, povo é figura polimórfica, em seus distintos apareceres na cena pública, de sorte que, em vez de uma visão estática, emerge da leitura dos textos dos Discursos uma visão dinâmica e em contínua transformação. Povo, para Maquiavel, é categoria política. Como tal, é vazia de conteúdos empíricos, quer de natureza sociológica (como, por exemplo, uma determinada classe social), quer econômica (como, por exemplo, pobres). Compreender povo como ator coletivo político é entender que seu ser se esgota em seu aparecimento na cena política. Antes - ou fora de seu aparecimento, é como se estivesse invisivel. O povo, uma vez alcançada uma reivindicação até então negada, "desaparece", para reaparecer em nova conjuntura crítica. Cada aparecimento é sempre por uma "face" determinada e não previsível. Neste trabalho, seguindo a senda aberta por Visentin (2013, 2015), caracterizamos três modos distintos desse aparecimento: povo como não-governo, povo como multidão e povo no príncipe. $\mathrm{O}$ que faz com que o povo apareça sob uma ou outra face é a conjuntura histórica concreta. Visto que as conjunturas históricas variam no tempo, variam também as "faces" sob as quais a cada vez o povo emerge na cena pública.

Apesar da singularidade dos aparecimentos, estes apresentam vários pontos em comum, dentre os quais destacamos os seguintes. Primeiro, cada aparecimento surge a partir da negatividade das necessidades das quais tomam consciência aqueles que estão "fora" do âmbito do exercício poder político, transformando-as em mobilizaçóes reivindicativas, as quais, quando obtêm êxito, resultam em ordini et leggi que fundam a liberdade da ordem política. Segundo, em cada uma das faces de povo descritas neste trabalho, povo é sempre exterior à estrutura de poder instituída. Sua negatividade consiste na sua condição de "náo-governo", o que faz com que esteja nele a origem de toda ordem jurídico-política da cidade. Terceiro, embora povo se defina pela negatividade, não é passividade ou matéria inerte a ser plasmada: a oposição a toda dominaçáo exercida pelos grandes e pelo príncipe é produtora de liberdade, ao dar origem a ordini et leggi. Quarto, nenhuma figura de povo dá origem à ideia de representação, sequer a de povo como multidão e de povo no príncipe. A parte é, para Maquiavel, um humor entre outros humores. Por isso, qualquer noção de representaçâo da totalidade social fica excluída. 
AMES, J. L. The multiple figures of people in Machiavelli's discourses. Trans/form/ação, Marília, v. 43, n. 2, p. 133-156, Abr./Jun., 2020.

\begin{abstract}
AвSTRACT: In the reading of the three major political works of Machiavelli is recurrent the use of the term popolo, or some correlate. Thus, if Machiavelli's interest in the figure "people" seems clear, what does he mean by it? Is it possible to establish a sufficiently homogeneous and definitive conception of people in Machiavellian thought, particularly in Discourses? The purpose of this study is to show that, although an idea of popolo as a political actor in Machiavelli's work is present, his conception is not definitively fixed, let alone that it can be homogeneous and static. Instead, it can be said that the conception of popolo in Discourses is polymorphic and varies according to the concrete historical conjunctures in which it emerges on the public scene, so that it is an idea in permanent and continuous transformation.
\end{abstract}

KeYwords: Machiavelli. People. Discourses on Livy. Freedom. Political participation.

\title{
REFERÊNCIAS
}

BORRELI, Gianfranco. Machiavelli, ragion di Stato, polizia Cristiana. Napoli: Cronopio, 2017.

DEL LUCCHESE, Filippo S’accoutumer à la diversité. Figures de la multitude chez Machiavel et Spinoza. Multitudes, n. 13, p. 141-149, 2003.

FROSINI, Fabio. E questa difficultà è ragionevole. La perdita della libertà nei Discorsi di Machiavelli. In: PANICHI, N. (a cura di) Figure di 'servitù' e 'dominio' nella cultura

filosofica europea tra Cinquecento e Seicento. Firenze: Le Lettere, p. 99-118, 2010.

ÍON, Cristina. Machiavel et les désirs du peuple. In: ZARKA, Ives Charles; ION, Cristina. Machiavel: Le pouvoir et le peuple. Paris: Mimesis, p. 139-155, 2015.

LANDI, Sandro. Les opinions Du peuple chez Machiavel. In: ZARKA, Ives Charles; ION, Cristina. Machiavel: Le pouvoir et le peuple. Paris: Mimesis, p. 123-137, 2015.

LEFORT, C. Le Travail de l'Oeuvre Machiavel. Paris: Éditions Gallimard, 1972.

MACHIAVELLI, Niccolò. Tutte le Opere. A cura di Mario Martelli. Firenze, Sansoni, 1992.

McCORMICK, John. Machiavellian Democracy. New York: Cambridge University Press, 2011.

SKINNER, Quentin. Maquiavel. Tradução de Maria Lucia Montes. São Paulo: Brasiliense, 1988.

SUCHOWLANSKI, Mauricio. Between Citizen \& Subject: Placing the People in Machiavelli's Political Imagination. Disponível em: http://papers.ssrn.com/sol3/papers. 
cfm?abstract_id=2314496. Trabalho apresentado em Annual Meeting of the American Political Science Association, Aug. 29-Sept. 1, 2013. Acesso em 31/08/2016.

VATTER, Miguel. Between Form and Event. Afterword to the paperback edition. Fordham University Press, 2014. Disponível em: https://www.academia.edu/7502218/ Between_Form_and_Event._Machiavellis_Theory_of_Political_Freedom. Acesso em 22/11/2017.

VISENTIN, Stefano. La virtù dei molti. Machiavelli e il repubblicanesimo olandese della seconda età del seicento. In: LUCCHESE, Filippo; SARTORELLO, Luca; VISENTIN, Stefano. Machivelli: Immaginazione e contingenza. Pisa: Edizioni ETS, 2006.

VISENTIN, Stefano. Tenere animato l'universale. Visibilità del popolo in Machiavelli. In: CAPORALI, Riccardo; MORFINO, Vittorio; VISENTIN, Stefano. Machiavelli: tempo e conflitto. Milano: Mimesis, p. 275-292, 2013.

VISENTIN, Stefano. The Different Faces of the People: On Machiavelli's Political Topography. In: DEL LUCCHESE, Filippo; FROSINI, Fabio; MORFINO, Vittorio. The Radical Machiavelli: Politics, Philosophy and Language. Leinden/Boston: Brill, 2015.

ZANCARINI, Jean-Claude. Les humeurs du corps politique: le peuple et la plébe chez Machiavel. Laboratoire italien. Politique et société. ENS éditions, p. 25-33, 2001.

Recebido: 30/4/2018

Aceito: 29/6/2019 